\title{
Flavobacterium glaciei sp. nov., a novel psychrophilic bacterium isolated from the China No.1 glacier
}

Correspondence

Pei-Jin Zhou

zhou@sun.im.ac.cn

\author{
De-Chao Zhang, ${ }^{1,2}$ He-Xiang Wang, ${ }^{2}$ Hong-Can Liu, ${ }^{1}$ Xiu-Zhu Dong ${ }^{1}$ \\ and Pei-Jin Zhou ${ }^{1}$
}

\author{
${ }^{1}$ State Key Laboratory of Microbial Resources, Institute of Microbiology, Chinese Academy of \\ Sciences, Beijing 100080, P. R. China \\ ${ }^{2}$ State Key Laboratory for Agrobiotechnology, College of Biological Sciences, China Agricultural \\ University, Beijing 100094, P. R. China
}

The genus Flavobacterium was proposed by Bergey et al. (1923). Since then, the description of the genus has been emended several times (Bernardet et al., 1996). It currently accommodates Gram-negative, non-spore-forming, yellowpigmented and rod-shaped bacteria that are usually motile by gliding, contain menaquinone $6(\mathrm{MK}-6)$ as the sole respiratory quinone and have a DNA G $+\mathrm{C}$ content in the range of $32-37 \mathrm{~mol} \%$. At the time of writing, the genus Flavobacterium comprises 37 recognized species (Aslam et al., 2005; Horn et al., 2005; Nogi et al., 2005; Van Trappen et al., 2005; Yi et al., 2005; Wang et al., 2006; Yoon et al., 2006). Members of the genus Flavobacterium have been isolated from a wide range of temperate habitats including diseased fish, freshwater and river sediments, seawater and marine sediments, soil and microbial mats. A number of cold-adapted Flavobacterium species have also been isolated from glaciers, sea ice and Antarctic lakes.

During a survey of psychrophilic organisms from the China No.1 glacier, located in Xinjiang Uygur Autonomous Region, north-west China, we isolated a novel psychrophilic bacterial strain. Physiological and biochemical features,

The GenBank/EMBL/DDBJ accession number for the 16S rRNA gene sequence of Flavobacterium glaciei sp. nov. strain $0499^{\top}$ is D0515962.

A table detailing the cellular fatty acid contents of Flavobacterium glaciei sp. nov. and related taxa is available as supplementary material in IJSEM Online. cellular fatty acid content, phylogenetic analysis based on the 16S rRNA gene sequence and DNA-DNA hybridization data indicated that the new isolate represents a novel species in the genus Flavobacterium.

Strain $0499^{\mathrm{T}}$ was isolated from frozen soil collected from the China No.1 glacier using previously described media and methods (Zhu et al., 2003). The strain was routinely grown aerobically at $21^{\circ} \mathrm{C}$ on PYG medium containing the following components $\left(\mathrm{l}^{-1}\right): 5 \mathrm{~g}$ bacto peptone (Difco), $0 \cdot 2 \mathrm{~g}$ yeast extract (Oxoid), $5 \mathrm{~g}$ glucose, $3 \mathrm{~g}$ beef extract (Oxoid), $0.5 \mathrm{~g} \mathrm{NaCl}$ and $1.5 \mathrm{~g} \mathrm{MgSO}_{4} .7 \mathrm{H}_{2} \mathrm{O}$ (pH adjusted to $7 \cdot 0)$. Flavobacterium succinicans DSM $4002^{\mathrm{T}}$ and Flavobacterium hydatis NBRC $14958^{\mathrm{T}}$ were obtained from DSMZ and NBRC, respectively. Flavobacterium granuli KCTC $12201^{\mathrm{T}}$ was kindly provided by Dr Sung-Taik Lee. These strains were cultivated as recommended (Bernardet et al., 1996; Aslam et al., 2005) and used as reference strains.

DNA was extracted and purified as described by Sambrook et al. (1989). The gene encoding $16 \mathrm{~S}$ rRNA was amplified by PCR with the forward primer 5'-AGAGTTTGATCCTGGCTCAG-3' and reverse primer 5'-AAGGAGGTGATCCAGCCGCA-3' (Liu et al., 2000). The PCR product was sequenced using the $\mathrm{ABI}$ BigDye 3.1 sequencing kit (Applied Biosystems) and an automated DNA sequencer (ABI3730; Applied Biosystems). BLASTn searches with the nearly complete (1424 bp) 16S rRNA gene sequence of strain $0499^{\mathrm{T}}$ 
performed in GenBank and EMBL revealed that the novel isolate shared high sequence similarity ( $97.9 \%)$ with members of the genus Flavobacterium. Phylogenetic trees were constructed using the neighbour-joining (Saitou \& Nei, 1987) and maximum-parsimony algorithms with Kimura's two-parameter model (Kimura, 1980) implemented in MEGA version 3.0 (Kumar et al., 2004). The resultant tree topologies were evaluated by bootstrap analysis based on 1000 replicates. Phylogenetic analysis (Fig. 1) based on a consensus $1145 \mathrm{bp}$ length of 16S rRNA gene sequences showed that strain $0499^{\mathrm{T}}$ grouped with members of the genus Flavobacterium and formed a distinct cluster with $F$. succinicans DSM $4002^{\mathrm{T}}(97 \cdot 9 \%)$, F. granuli KCTC $12201^{\mathrm{T}}$ $(97 \cdot 4 \%)$ and F. hydatis NBRC $14958^{\mathrm{T}}(97 \cdot 2 \%)$. Very similar tree topologies were obtained using the two different algorithms.

Colony morphology was observed on PYG medium after incubation at $21^{\circ} \mathrm{C}$ for $24-48 \mathrm{~h}$. Cell morphology was examined under a light microscope (BH-2; Olympus) using bacteria grown under the same conditions. The temperature range for growth was determined with a TN3F temperaturegradient incubator (Advantec). The $\mathrm{pH}$ range for growth was determined in PYG medium adjusted to various $\mathrm{pH}$ values with $\mathrm{HCl}$ or $\mathrm{NaOH}\left(1 \mathrm{M} \mathrm{l}^{-1}\right)$. Catalase, oxidase, arginine dihydrolase, lysine decarboxylase, ornithine decarboxylase, lecithinase and tryptophan deaminase activities, the Voges-Proskauer and the Simmons' citrate tests and the utilization of various substrates as sole carbon and energy source were examined according to Dong \& Cai (2001). Acid production from carbohydrates was determined as described by Leifson (1963). Anaerobic growth was investigated in PYG medium in an anaerobic test tube filled with nitrogen gas. The presence of gliding motility was determined as described by Zhu et al. (2003). Congo red adsorption was tested by directly flooding some colonies on agar plates with $0.01 \%$ aqueous Congo red solution. The detection of flexirubin-type pigments using $20 \%(w / v) \mathrm{KOH}$ was performed according to Reichenbach (1989). Other physiological tests were conducted as described by Wang et al. (2006). Cells of strain $0499^{\mathrm{T}}$ were rod-shaped, Gram-negative, non-flagellated and nongliding. Colonies on PYG agar were yellow, smooth, circular and convex with entire margins. Strain $0499^{\mathrm{T}}$ was distinguished from its nearest phylogenetic relatives, $F$. succinicans, F. granuli and F. hydatis by the following phenotypic characteristics: (i) strain $0499^{\mathrm{T}}$ was an obligate aerobic and non-gliding bacterium, whereas both $F$. succinicans and $F$. hydatis were facultatively anaerobic and motile; (ii) strain $0499^{\mathrm{T}}$ grew weakly on agar at $25^{\circ} \mathrm{C}$, whereas the optimal growth temperature of its phylogenetic relatives was $25-30{ }^{\circ} \mathrm{C}$; (iii) strain $0499^{\mathrm{T}}$ did not produce

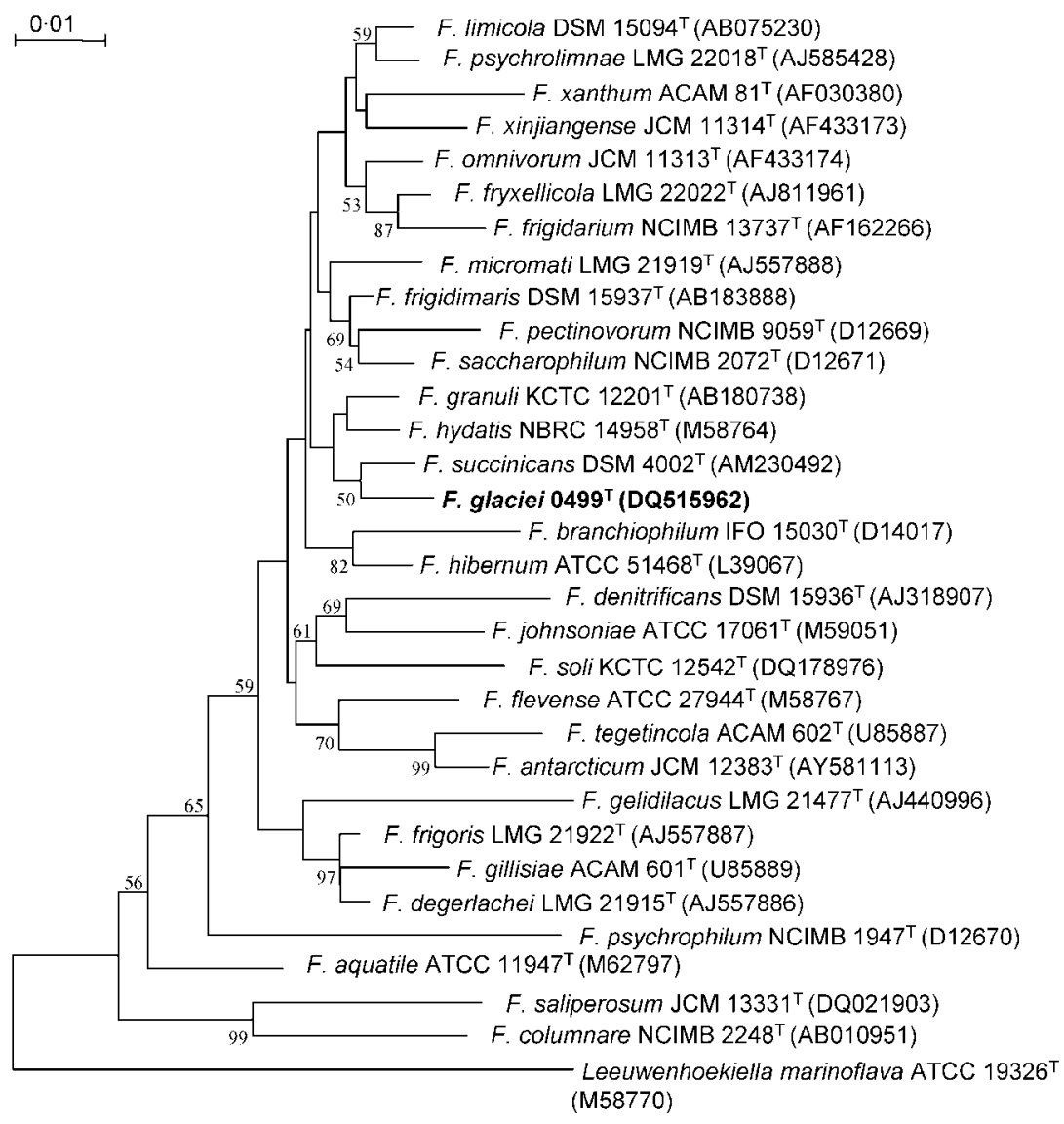

Fig. 1. Neighbour-joining tree based on 16S rRNA gene sequences showing the phylogenetic relationships of strain $0499^{\top}$ and related species. The tree was rooted with Leeuwenhoekiella marinoflava. Numbers at nodes represent the bootstrap values (\% of 1000 resampled datasets) greater than $50 \%$. GenBank accession numbers are given in parentheses. Bar, $1 \%$ sequence divergence. 
$\beta$-galactosidase, contrary to its phylogenetic relatives. Other phenotypic features that differentiated strain $0499^{\mathrm{T}}$ from its phylogenetic relatives and from some other psychrophilic Flavobacterium species are given in the species description and Table 1.

Respiratory quinones were extracted and purified according to Collins (1985) and were analysed by HPLC (Wu et al., 1989) using menaquinone 6 (MK-6) from F. granuli KCTC $12201^{\mathrm{T}}$ as a reference. Cellular fatty acids were determined from a culture grown in PYG at $21^{\circ} \mathrm{C}$ for 3 days and were extracted, methylated and analysed using the standard MIDI (Microbial Identification) procedure (Sasser, 1990). Cells of strain $0499^{\mathrm{T}}$ contained menaquinone 6 (MK-6) as the major respiratory quinone. The predominant cellular fatty acids of strain $0499^{\mathrm{T}}$ were $\mathrm{C}_{15: 0}(13.9 \%)$, summed feature 3 $\left(\mathrm{C}_{16: 1} \omega 7 c /\right.$ iso- $\left.\mathrm{C}_{15: 0} \quad 2-\mathrm{OH}, 10 \cdot 0 \%\right), \mathrm{C}_{17: 1} \omega 6 c(9 \cdot 5 \%)$, anteiso- $\mathrm{C}_{15: 0} \quad(8 \cdot 3 \%), \quad$ iso- $\mathrm{C}_{15: 0} \quad(8 \cdot 2 \%), \quad$ iso- $\mathrm{C}_{15: 1}$ $(6 \cdot 2 \%)$, iso- $\mathrm{C}_{15: 0} 3-\mathrm{OH}(5 \cdot 2 \%)$ and $\mathrm{C}_{15: 1} \omega 6 c(5 \cdot 2 \%)$. The fatty acid profile of strain $0499^{\mathrm{T}}$ resembled those of other Flavobacterium species (Bernardet et al., 1996). Strain $0499^{\mathrm{T}}$ also contained the unsaturated fatty acid $\mathrm{C}_{17: 1} \omega 8 \mathrm{c}$
$(3 \cdot 0 \%)$ and the hydroxylated fatty acid $\mathrm{C}_{17: 0} 3-\mathrm{OH}(1 \cdot 4 \%)$ that are not commonly found in other Flavobacterium species. Detailed fatty acid profiles for strain $0499^{\mathrm{T}}$, its closest phylogenetic relatives and some other psychrophilic Flavobacterium species are available in Supplementary Table S1 in IJSEM Online.

The DNA G + C content of strain $0499^{\mathrm{T}}$ was determined using the thermal denaturation method (Sly et al., 1986). DNADNA hybridization experiments were performed at $65 \cdot 6^{\circ} \mathrm{C}$ using the liquid renaturation method (De Ley et al., 1970) as modified by Huß et al. (1983). Both experiments were carried out using a DU800 spectrophotometer (Beckman). The DNA $\mathrm{G}+\mathrm{C}$ content of strain $0499^{\mathrm{T}}$ was $36 \cdot 5 \mathrm{~mol} \%$. DNA-DNA relatedness between strain $0499^{\mathrm{T}}$ and F. succinicans DSM $4002^{\mathrm{T}}$, F. granuli KCTC $12201^{\mathrm{T}}$ and F. hydatis NBRC $14958^{\mathrm{T}}$ was $48 \cdot 4 \%, 44 \cdot 1 \%$ and $31.9 \%$, respectively.

Based on phenotypic, chemotaxonomic and molecular data, it is concluded that strain $0499^{\mathrm{T}}$ represents a novel species of the genus Flavobacterium, for which the name Flavobacterium glaciei sp. nov. is proposed.

Table 1. Differential characteristics of Flavobacterium glaciei, close phylogenetic relatives and some psychrophilic Flavobacterium species

Taxa: 1. F. glaciei $0499^{\mathrm{T}}$; 2. F. succinicans DSM $4002^{\mathrm{T}}$ (Bernardet et al., 1996); 3. F. granuli KCTC 12201 ${ }^{\mathrm{T}}$ (Aslam et al., 2005); 4. F. hydatis NBRC $14958^{\mathrm{T}}$ (Bernardet et al., 1996); 5. Flavobacterium xinjiangense JCM 11314 ${ }^{\mathrm{T}}$ (Zhu et al., 2003); 6. Flavobacterium omnivorum JCM $11313^{\mathrm{T}}$ (Zhu et al., 2003); 7. Flavobacterium gillisiae ACAM 601 ${ }^{\mathrm{T}}$ (McCammon et al., 2000); 8. Flavobacterium tegetincola ACAM 602 ${ }^{\mathrm{T}}$ (McCammon et al., 2000); 9. Flavobacterium gelidilacus LMG $21477^{\mathrm{T}}$ (Van Trappen et al., 2003); 10. Flavobacterium frigidimaris DSM $15937^{\mathrm{T}}$ (Nogi et al., 2005); 11. Flavobacterium antarcticum JCM $12383^{\mathrm{T}}$ (Yi et al., 2005). +, Positive; -, negative; (+) weakly positive; V, variable among strains; ND, no data available.

\begin{tabular}{|c|c|c|c|c|c|c|c|c|c|c|c|}
\hline Characteristic & 1 & 2 & 3 & 4 & 5 & 6 & 7 & 8 & 9 & 10 & 11 \\
\hline Nutrient agar & + & + & + & + & $(+)$ & + & + & + & + & + & + \\
\hline Trypticase soy agar & + & + & + & + & - & + & + & + & + & + & + \\
\hline Growth at $25^{\circ} \mathrm{C}$ & $(+)$ & + & + & + & - & - & $(+)$ & $(+)$ & $(+)$ & $(+)$ & $(+)$ \\
\hline Gliding motility & - & + & - & + & - & - & - & + & - & + & - \\
\hline Acid from carbohydrates & - & + & - & + & - & - & + & + & - & + & + \\
\hline \multicolumn{12}{|l|}{ Degradation of: } \\
\hline Aesculin & + & + & $\mathrm{ND}$ & + & + & + & + & - & - & + & - \\
\hline Casein & + & + & - & + & + & + & + & - & + & + & + \\
\hline Chitin & - & - & - & $(+)$ & + & + & + & - & - & + & - \\
\hline Tyrosine & - & - & - & + & - & - & - & - & - & $\mathrm{ND}$ & - \\
\hline $\mathrm{H}_{2} \mathrm{~S}$ production & - & + & - & - & + & - & - & - & - & - & - \\
\hline Nitrate reduction & + & $\mathrm{V}$ & - & + & - & + & - & - & - & - & - \\
\hline$\beta$-Galactosidase activity & - & + & + & + & - & + & - & - & - & + & - \\
\hline Mean DNA G + C content $(\mathrm{mol} \%)$ & 36 & 36 & 36 & 34 & 34 & 35 & 32 & 32 & 30 & 34 & 38 \\
\hline
\end{tabular}




\section{Description of Flavobacterium glaciei sp. nov.}

Flavobacterium glaciei (gla.ci'ei. L. gen. n. glaciei of ice, referring to the isolation source, the China No.1 glacier).

Cells are Gram-negative rods, non-flagellated and nongliding, $0 \cdot 45-0 \cdot 55 \mu \mathrm{m}$ wide and $2 \cdot 7-6 \cdot 3 \mu \mathrm{m}$ long. Colonies are yellow, smooth, circular and convex with entire margins and do not absorb Congo red. Psychrophilic and obligately aerobic. Produce catalase and cytochrome oxidase. Growth occurs at $4-25^{\circ} \mathrm{C}$ and $\mathrm{pH} 6 \cdot 0-9 \cdot 0$, with optimum growth at $21{ }^{\circ} \mathrm{C}$ and approximately pH $6 \cdot 5-7 \cdot 5$. Growth occurs in the presence of $0-1 \%(\mathrm{w} / \mathrm{v}) \mathrm{NaCl}$. Nitrate is reduced. Cells do not contain flexirubin-type pigments. Arginine dihydrolase, lysine decarboxylase, ornithine decarboxylase, lecithinase and tryptophan deaminase activities are absent. Simmons' citrate and Voges-Proskauer tests are negative. Hydrolyses gelatin, casein, starch and aesculin, but not agar, alginate, carboxymethylcellulose, chitin, pectin, DNA or urea. Acid and gas are not produced from carbohydrates. The following substrates are utilized as sole carbon source: D-glucose, maltose, sucrose, D-trehalose, D-mannose, dextrin, proline, L-glutamic acid and glucose 1-phosphate. The following substrates are not utilized as sole carbon source: fructose, fucose, D-galactose, L-arabinose, D-cellobiose, L-rhamnose, lactose, raffinose, D-melibiose, D-sorbitol, turanose, xylitol, glycerol, inositol, erythritol, serine, threonine, alanine, histidine, leucine, aspartic acid, malonic acid, lactic acid, acetic acid, citric acid, pyruvate, succinate or uridine. Cells contain menaquinone $6(\mathrm{MK}-6)$. The cellular fatty acids are $\mathrm{C}_{15: 0}(13.9 \%)$, summed feature $3\left(\mathrm{C}_{16: 1} \omega 7 c /\right.$ iso- $\mathrm{C}_{15: 0} 2$ $\mathrm{OH}, 10 \cdot 0 \%), \mathrm{C}_{17: 1} \omega 6 c(9 \cdot 5 \%)$, anteiso- $\mathrm{C}_{15: 0}(8 \cdot 3 \%)$, iso$\mathrm{C}_{15: 0}(8 \cdot 2 \%)$, iso- $\mathrm{C}_{15: 1}(6 \cdot 2 \%)$, iso- $\mathrm{C}_{15: 0} 3-\mathrm{OH}(5 \cdot 2 \%)$, $\mathrm{C}_{15: 1} \omega 6 c(5 \cdot 2 \%)$, iso- $\mathrm{C}_{17: 0} \quad 3-\mathrm{OH} \quad(4 \cdot 2 \%), \mathrm{C}_{17: 1} \omega 8 c$ $(3.0 \%)$, iso- $\mathrm{C}_{16: 0} 3-\mathrm{OH}(3 \cdot 0 \%)$, iso- $\mathrm{C}_{17: 1} \omega 9 c(2 \cdot 7 \%)$, $\mathrm{C}_{16: 0}(2 \cdot 1 \%), \mathrm{C}_{15: 0} 3-\mathrm{OH}(2 \cdot 0 \%), \mathrm{C}_{16: 0} 3-\mathrm{OH}(1 \cdot 7 \%)$, anteiso- $\mathrm{C}_{15: 1}(1 \cdot 4 \%)$ and $\mathrm{C}_{17: 0} 3-\mathrm{OH}(1 \cdot 4 \%)$. The $\mathrm{G}+\mathrm{C}$ content of the DNA is $36 \cdot 5 \mathrm{~mol} \%$.

The type strain, $0499^{\mathrm{T}}\left(=\right.$ CGMCC $\left.1.5380^{\mathrm{T}}=\mathrm{JCM} 13953^{\mathrm{T}}\right)$ was isolated from the China No.1 glacier in the Xinjiang Uygur Autonomous Region.

\section{Acknowledgements}

We are grateful to Dr Sung-Taik Lee for providing the type strain of Flavobacterium granuli. This work was supported by the National Basic Research Program of China (2004CB719601).

\section{References}

Aslam, Z., Im, W.-T., Kim, M. K. \& Lee, S.-T. (2005). Flavobacterium granuli sp. nov., isolated from granules used in a wastewater treatment plant. Int J Syst Evol Microbiol 55, 747-751.

Bergey, D. H., Harrison, F. C., Breed, R. S., Hammer, B. W. \& Huntoon, F. M. (editors) (1923). Genus II. Flavobacterium gen. nov. In Bergey's Manual of Determinative Bacteriology, pp. 1-442. Baltimore: Williams \& Wilkins.
Bernardet, J. F., Segers, P., Vancanneyt, M., Berthe, F., Kersters, K. \& Vandamme, P. (1996). Cutting a Gordian knot: emended classification and description of the genus Flavobacterium, emended description of the family Flavobacteriaceae, and proposal of Flavobacterium hydatis nom. nov. (basonym, Cytophaga aquatilis Strohl and Tait 1978). Int J Syst Bacteriol 46, 128-148.

Collins, M. D. (1985). Isoprenoid quinone analysis in classification and identification. In Chemical Methods in Bacterial Systematics, pp. 267-287. Edited by M. Goodfellow \& D. E. Minnikin. London: Academic Press.

De Ley, J., Cattoir, H. \& Reynaerts, A. (1970). The quantitative measurement of DNA hybridization from renaturation rates. Eur J Biochem 12, 133-142.

Dong, X.-Z. \& Cai, M.-Y. (editors) (2001). Determination of biochemical properties. In Manual for the Systematic Identification of General Bacteria, pp. 370-398. Beijing: Science Press (in Chinese).

Horn, M. A., Ihssen, J., Matthies, C., Schramm, A., Acker, G. \& Drake, H. L. (2005). Dechloromonas denitrificans sp. nov., Flavobacterium denitrificans sp. nov., Paenibacillus anaericanus sp. nov. and Paenibacillus terrae strain $\mathrm{MH} 72, \mathrm{~N}_{2} \mathrm{O}$-producing bacteria isolated from the gut of the earthworm Aporrectodea caliginosa. Int J Syst Evol Microbiol 55, 1255-1265.

Huß, V. A. R., Festl, H. \& Schleifer, K.-H. (1983). Studies on the spectrophotometric determination of DNA hybridization from renaturation rates. Syst Appl Microbiol 4, 184-192.

Kimura, M. (1980). A simple method for estimating evolutionary rates of base substitutions through comparative studies of nucleotide sequences. J Mol Evol 16, 111-120.

Kumar, S., Tamura, K. \& Nei, M. (2004). MEGA3: integrated software for molecular evolutionary genetics analysis and sequence alignment. Brief Bioinform 5, 150-163.

Leifson, E. (1963). Determination of carbohydrate metabolism of marine bacteria. J Bacteriol 85, 1183-1184.

Liu, H., Xu, Y., Ma, Y. \& Zhou, P. (2000). Characterization of Micrococcus antarcticus sp. nov., a psychrophilic bacterium from Antarctica. Int J Syst Evol Microbiol 50, 715-719.

McCammon, S. A. \& Bowman, J. P. (2000). Taxonomy of Antarctic Flavobacterium species: description of Flavobacterium gillisiae sp. nov., Flavobacterium tegetincola sp. nov. and Flavobacterium xanthum sp. nov., nom. rev. and reclassification of [Flavobacterium] salegens as Salegentibacter salegens gen. nov., comb. nov. Int J Syst Evol Microbiol 50, 1055-1063.

Nogi, Y., Soda, K. \& Oikawa, T. (2005). Flavobacterium frigidimaris sp. nov., isolated from Antarctic seawater. Syst Appl Microbiol 28, 310-315.

Reichenbach, H. (1989). Order I. Cytophagales Leadbetter 1974. In Bergey's Manual of Systematic Bacteriology, vol. 3, pp. 2011-2013. Edited by J. T. Staley, M. P. Bryant, N. Pfennig \& J. G. Holt. Baltimore: Williams \& Wilkins.

Saitou, N. \& Nei, M. (1987). The neighbor-joining method: a new method for reconstructing phylogenetic trees. Mol Biol Evol 4, 406-425.

Sambrook, J., Fritsch, E. F. \& Maniatis, T. (1989). Molecular Cloning: a Laboratory Manual, 2nd edn. Cold Spring Harbor, NY: Cold Spring Harbor Laboratory.

Sasser, M. (1990). Identification of Bacteria by Gas Chromatography of Cellular Fatty Acids, MIDI Technical Note 101. Newark, DE: MIDI Inc.

Sly, L. I., Blackall, L. L., Kraat, P. C., Tian-Shen, T. \& Sangkhobol, V. (1986). The use of second derivative plots for the determination of mol\% guanine plus cytosine of DNA by the thermal denaturation method. J Microbiol Methods 5, 139-156. 
Van Trappen, S., Mergaert, J. \& Swings, J. (2003). Flavobacterium gelidilacus sp. nov., isolated from microbial mats in Antarctic lakes. Int J Syst Evol Microbiol 53, 1241-1245.

Van Trappen, S., Vandecandelaere, I., Mergaert, J. \& Swings, J. (2005). Flavobacterium fryxellicola $\mathrm{sp}$. nov. and Flavobacterium psychrolimnae sp. nov., novel psychrophilic bacteria isolated from microbial mats in Antarctic lakes. Int J Syst Evol Microbiol 55, 769-772.

Wang, Z. W., Liu, H. Y., Dai, X., Wang, B. J., Jiang, C. Y. \& Liu, S.-J. (2006). Flavobacterium saliperosum sp. nov., isolated from freshwater lake sediment. Int J Syst Evol Microbiol 56, 439-442.
Wu, C., Lu, X., Qin, M., Wang, Y. \& Ruan, J. (1989). Analysis of menaquinone compound in microbial cells by HPLC. Microbiology (English translation of Mikrobiologiya) 16, 176-178.

Yi, H., Oh, H.-M., Lee, J.-H., Kim, S.-J. \& Chun, J. (2005). Flavobacterium antarcticum sp. nov., a novel psychrotolerant bacterium isolated from the Antarctic. Int J Syst Evol Microbiol 55, 637-641.

Yoon, J.-H., Kang, S.-J. \& Oh, T.-K. (2006). Flavobacterium soli sp. nov., isolated from soil. Int J Syst Evol Microbiol 56, 997-1000.

Zhu, F., Wang, S. \& Zhou, P. (2003). Flavobacterium xinjiangense sp. nov. and Flavobacterium omnivorum sp. nov., novel psychrophiles from the China No. 1 glacier. Int J Syst Evol Microbiol 53, 853-857. 